of 188 cases of subphrenic abscess. The pathology, clinical features and treatment of the condition are examined. A special plea is made for the use of the extra-serous route in drainage. A very useful bibliography is added but it is regrettable that in a fairly expensive book the $x$-ray plates have been so badly arranged both in space and in juxtaposition. I.L.E.

\section{THORACIC SURGICAL MANAGEMENT}

By J. R. BELCHER, M.S., F.R.C.S. and I. W. B. Grant, M.B., F.R.C.P. 2nd Edition. Pp. ix + 216, with 78 diagrams. London: Baillière, Tindall \& Cox Ltd. 1955. 2 is.

This accurately titled book is well written, clearly set out and admirably illustrated. It should be an early acquisition for the library of everyone who is concerned with the surgical treatment of thoracic disease and it is equally useful for surgeon and physician, doctor and student.

A minor criticism is the prominence given in print and in illustration to the plastic nose-bag type of oxygen mask. The subsequent paragraph on carbon dioxide retention is not an adequate warning against the dangers of rebreathing inherent in the use of such a mask.

I.L.E.

\section{POSTGRADUATE OBSTETRICS AND GYNAECOLOGY}

By F. J. Browne, M.D., D.Sc., F.R.C.S., F.R.C.O.G. and J. C. MCCluRE BROWNE, B.Sc., M.D., B.S., F.R.C.S., F.R.C.O.G. Second Edition. Pp. viii +688 , with I4I illustrations. Index Pp. 38. London: Butterworth \& Co. Ltd. 1955. 70s.

This is an excellent book. The first edition was good, but the second edition is still better, and in fact, it contains most of what a postgraduate requires to know to satisfy the examiners in a higher degree in obstetrics and gynaecology.

It is true that Browne quoted direct will not please most examiners, because the reading of condensations of literature is rather frowned on, but this fault can easily be made good because at the end of each chapter is a full and valuable bibliography.

Especially praiseworthy in the new edition is a chapter on Infertility which is now quite lengthy and seems to cover, better than in any other textbook on gynaecology, the whole subject of male and female infertility.

Although the book is 'safe,' and in certain chapters such as the conduct of the third stage of labour, tends to be alomst too safe, the modern viewpoint is succinctly expressed.

Even though it is a big book to read from cover to cover, it still should be bought because there is nothing quite like it as a book of reference. As with so many books of reference, that have been well written, one is tempted to read far more this the original matter one wished to check.

This book is authoritative and should recognised as such.

E.E.P. $\stackrel{2}{\complement}$

\section{PAIN}

Its Mechanisms and Neurosurgical Contrô By James C. White, M.D., F.A.C.S., and Williafl A. SweET, M.D., F.A.C.S. Pp. xxiv +73 B, with 134 illustrations. Oxford: Blackwell Scientific Publications. 1955. $£ 66 \mathrm{~s}$.

This is a unique book which more than fulfils the claims of its sub-title. It is a masterly neurost surgical treatise, reflecting uniformly in the diverse range of its chapters the experience and judgme of its authors.

It should have a wide appeal to many other thäg. neurosurgeons for the clear guidance it gives as t the range and limitations of neurosurgical contref of pain. General surgeons or physicians may $16 \mathrm{e}$ tempted to read first the last two chapters which deal with visceral pain in abdominal and thoracic disease. They will then almost certainly be stimulated to a thorough study of the whole book which cuts across all types of medical practice at $\overrightarrow{\mathrm{so}}$ many points.

Its size may at first sight be discouraging bu unlike many such large volumes, it is written in clear, concise and unobtrusive style. It is a roge worthy addition to the classics of medical literature

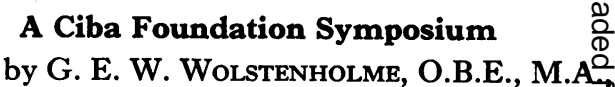
Edited by G. E. W. Wolstenholme, O.B.E., M.A
M.B., B.Ch., and MARgaret P. CAMERoN, M.A요

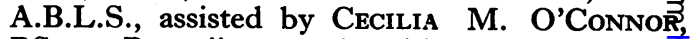
BS.c. Pp. xii +396 , with 69 illustration $\overrightarrow{8}$ London: J. \& A. Churchill Ltd. 1955. 428.

The Ciba Foundation is progressively placin the Medical Profession in its debt by arranging symposia of which this on Experimental Tubers culosis is the latest. Experts in a subject meet and receive hospitality from the Foundation at its house and there discuss some subject of importance on which co-ordination of observations and ideas from the various countries seems desirable. The numbers attending are very strictly limited to the well-know authorities with a sprinkling of younger workers. associated with them. As a result of this method af selection, the discussion of the papers is particularlis informal and searching and many readers will find the virtually expurgated reporting of this even more enlightening than the set papers themselves.

The main material consists of 23 papers on tuberculosis with individual discussions and four on experimental leprosy followed by a joint discussion? In many of these the approach is frankly experit mental and not easily applicable to clinical medicine 